原著

胃癌における術前 CEA，CA19-9值と手術予後についての検討

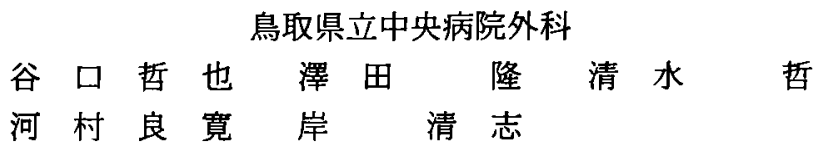

当科における最近 7 年間の胃癌手術症例552例を対象に術前血清 CEA, CA19-9值と予 後との関係を検討した。

全体としての術前 CEA 陽性率は $18.5 \%$, CA19-9陽性率は $19.5 \%$, stage の進行とと もに陽性率は上昇した. 全症例を対象とすると CEA および CA19-9陽性例は陰性例に比 べ有意に予後不良で, 特に CEA $10 \mathrm{ng} / \mathrm{ml}$ 以上および CA19-9 50U/ $\mathrm{ml}$ 以上の予後は不良 であった.

これらを stage 別にみると, 進行した stage III, IV では予後に差がみられなかったの に対し, CEA に関しては stage I, II で, CAI9-9に関しては stage II においてそれぞれ の陽性例の予後は陰性例に比べ有意に不良であった。

これら stage I, II についてリンパ管侵襲 (ly), 静脈侵襲 (v) との関連をみてみると, stage I では CEA，CA19-9ともに陽性例でly陽性率が有意に高く, CA19-9陽性例では v 陽性率が高かった。一方 stage II では関連がみられなかった。

以上より進行度の低い胃癌に関しては術前 CEA，CA19-9の値は有用な予後因子にな ると考えられた。

索引用語：胃癌, 術前 CEA 值, 術前 CA19-9值, 胃癌手術予後

\section{緒言}

CEA, CA19-9は消化器悪性腫場の代表的腫場マー カーであり, 胃癌においてもその診断, 再発の予知等 に広く臨床応用されている1出).一方, 胃癌の悪性度に 関しては予後との関連から病理組織学的にあるいは最 近では分子生物学的に検討が進められているが, 今回 われわれは胃癌患者の術前 CEA, CA19-9值と手術予 後との関係について検討したので報告する。

\section{対象と方法}

1988年 1 月から1994年12月までの 7 年間に当科で手 術が施行された胃癌552例を対象に, 術前 CEA, CA199を測定し, stage 別に術後の予後との関連につき検討 した.また，一部の症例については静脈侵襲（v),リ ンパ管侵襲 (ly), 深達度など, 病理組織学的事項との 関連についても検討を行った. なお stage 分類および 病理組織学的事項については胃癌取扱い規約第11版 に基づいて行った.生存率算出は Kaplan-Meiyer 法を

1997年 2 月 6 日受付 1997 年 5 月21日採用
用い，その有意差検定には一般化 Wilcoxon 法を用い た. 統計学的有意差検定は $\chi^{2}$ 検定を用いた。

CEA の cut off 值は $5.0 \mathrm{ng} / \mathrm{ml}$, CA19-9の cut off 值 は50U/mlであった.

\section{結 果}

\section{1. 術前 CEA, CA19-9の stage 別陽性率}

胃癌552例中, CEA は513例, CA19-9は505例に測定 された。術前 CEA 陽性率は stage I 14.8\%, II 8.9\%, III 15.7\%, IV 35.5\%であった。一方, 術前 CA19-9陽 性率は stage I 7.7\%, II 16.1\%, III $22.0 \%$, IV $49.5 \%$ で, 両者とも stage の進行とともに高くなり，特に

表 1 術前 CEA, CA19-9の stage 別陽性率

\begin{tabular}{c|c|c}
\hline stage & CEA 陽性率 & CA19-9陽性率 \\
\hline I & $14.8 \%$ & $7.7 \%$ \\
II & $8.9 \%$ & $16.1 \%$ \\
IIl & $15.7 \%$ & $22.0 \%$ \\
IV & $35.5 \%$ & $49.5 \%$ \\
\hline 合計 & $18.5 \%$ & $19.5 \%$ \\
\hline
\end{tabular}



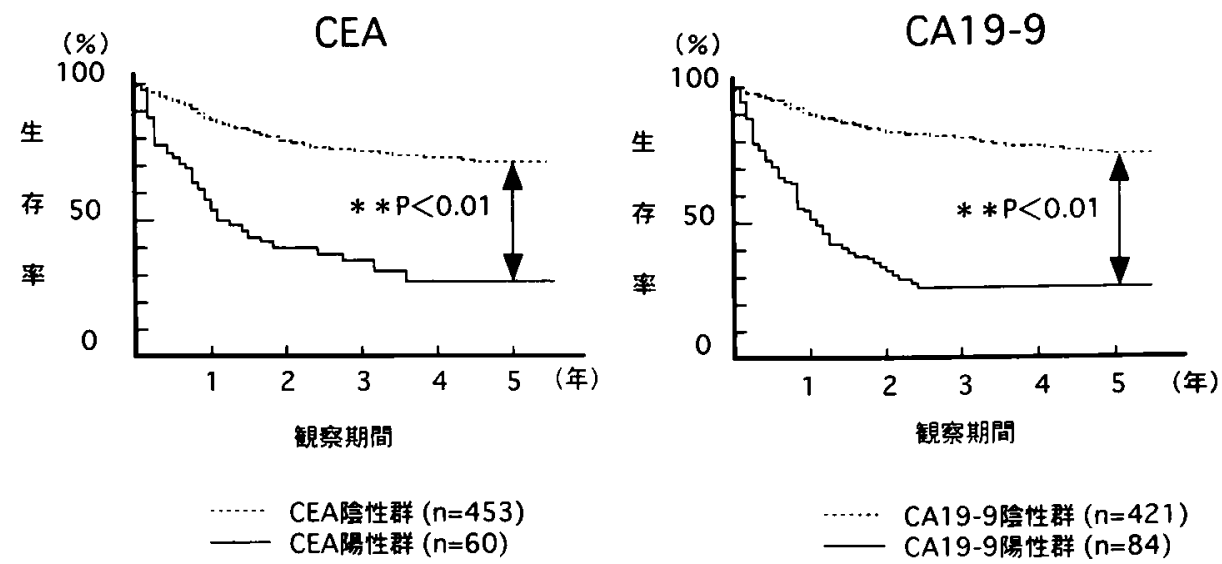

図 1 術前 CEA, CA19-9陽性群と陰性群と生存曲線の比較

CEA

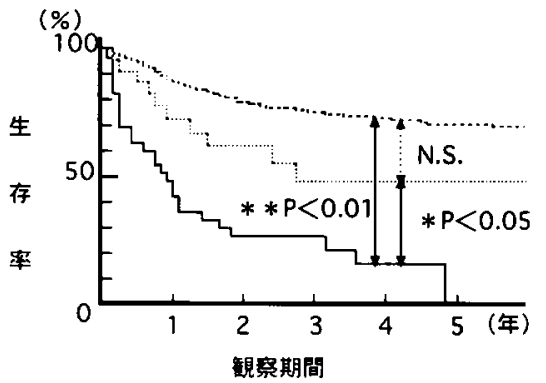

CEA $5 n g / m l$ 末满 $(n=453)$

$5 \mathrm{ng} / \mathrm{ml}$ 以上 $10 \mathrm{ng} / \mathrm{ml}$ 末満 $(n=24)$

$10 \mathrm{ng} / \mathrm{me}$ 以上 $(n=36)$
CA19-9

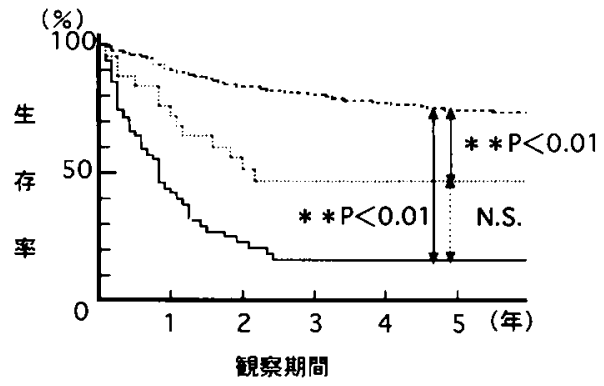

CA19-9 50U/me未満 $(n=421)$ $50 U / \mathrm{m} R$ 以上 $100 \mathrm{U} / \mathrm{ml}$ 未満 $(n=27)$ $100 \mathrm{U} / \mathrm{ml}$ 以上 $(n=57)$

図 2 術前 CEA，CA19-9值と生存曲線

stage IV での陽性率が高い傾向にあった。なお全症例 における陽性率は CEA 18.5\%。，CA19-9 19.5\%とそれ ほど高くなかった（表 1).

\section{2. 術前 CEA, CA19-9陽性群と陰性群との生存曲線} の比較

全症例を対象に術前腫瘍マーカー陽性群と陰性群の 術後生存曲線を比較すると, CEA, CA19-9ともに陽性 群の予後は陰性群に比べ有意に不良であった（図1）。

\section{3. 術前 CEA, CA19-9值と生存曲線の比較}

次に CEA の值を $5.0 \mathrm{ng} / \mathrm{ml}$ 末満, $5.0 \sim 10 \mathrm{ng} / \mathrm{ml}, 10$ $\mathrm{ng} / \mathrm{ml}$ 以上の 3 群に分け, また, CA19-9は50U/ $\mathrm{ml}$ 末 満, $50 \sim 100 \mathrm{U} / \mathrm{ml}, 100 \mathrm{U} / \mathrm{ml}$ 以上の 3 群に分け, 各々 における術後生存曲線を比較すると,CEAについては $10 \mathrm{ng} / \mathrm{ml}$ 以上の群は他の 2 群と比べ有意に予後不良 であり，5年生存例はみられなかった。一方，CA19-9
については, $50 \mathrm{U} / \mathrm{ml}$ 末満の群に比べ, 他の 2 群は有意 に予後不良であった（図2）。

4. stage 別にみた術前 CEA 陽性群と陰性群の生 存曲線の比較

stage 別に術前 CEA 陽性群と陰性群の生存曲線を 比較してみると stage III, IVでは両群に差が認められ なかったが, stage I，II では術前 CEA 陽性群の予後 が有意に不良であった。また stage IV の陽性例では 3 年生存はわずか 1 例のみであった（図了）.

5. 他病死症例を除いた stage I, II の術前 CEA 陽 性群と陰性群の生存曲線の比較

術後の生存曲続に有意差のみられた stage Iおよび II に関して, 癌と直接関わりのない他病死症例を除い て CEA 陽性群と陰性群の生存曲線を比較してみた が, CEA 陽性群の予後は陰性群に比べ有意に不良て 

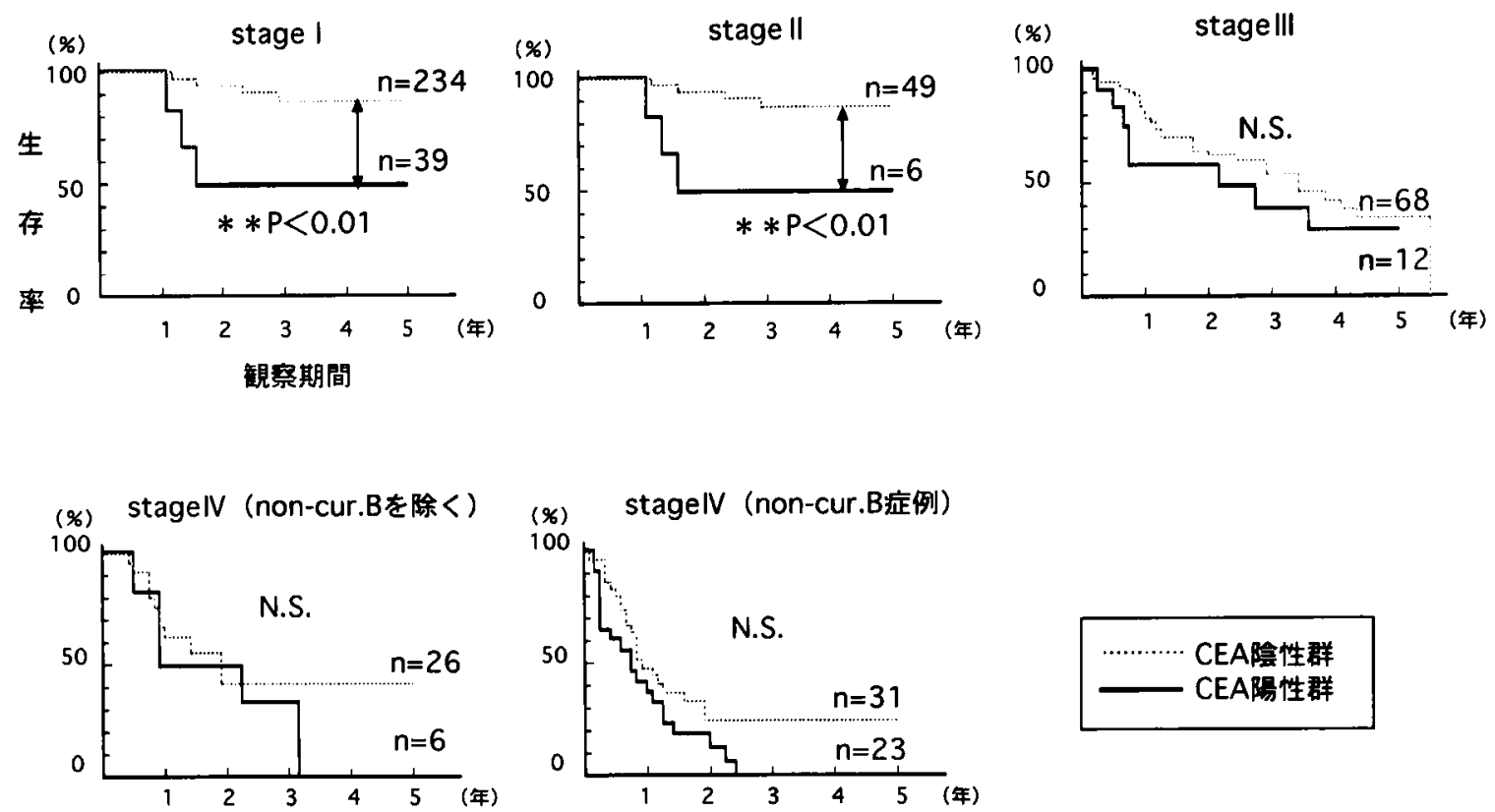

図 3 術前 CEA 值からみた stage 別生存曲線
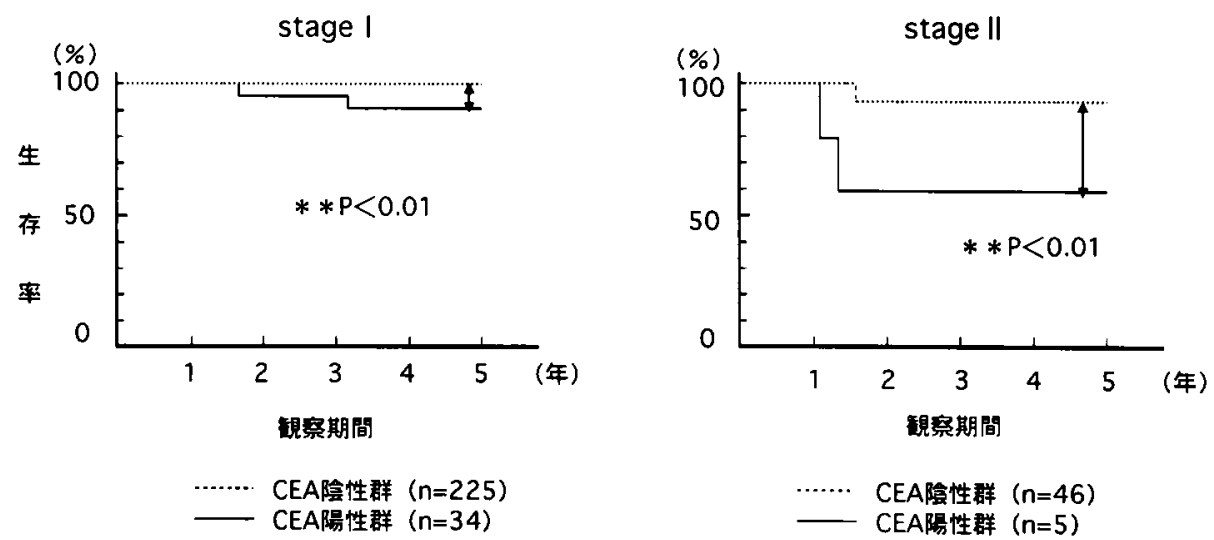

図 4 他病死症例を除いた stage I, II の CEA 陽性群と陰性群の生存曲線の比較

あった（図 4).

6. stage 別にみた術前 CA19-9陽性群と陰性群の生 存曲線の比較

stage 別に術前 CA19-9陽性群と陰性群の生存曲線 を比較してみると stage I, III, IVでは両群に差が認 められなかったが, stage II では術前CA19-9陽性群の 予後が有意に不良であった（図 5 )。

7. 他病死症例を除いた stage I, II の術前 CA19-9 陽性群と险性群の生存曲線の比較

CEA と同様に stage I およびII に関して他病死例
を除き, CA19-9陽性群と陰性群の生存曲線を比較して みたが, stage II のCA19-9陽性群の予後は陰性群に比 べ有意に不良であった（図6)。

8. 他病死症例を除いた stage I, II 症例の病理組織 学的因子

他病死症例を除いた stage I, II 症例について CEA, CA19-9の陽性, 陰性と $1 \mathrm{y}, \mathrm{v}$, 深達度との関係につい てみてみると, stage Iに関してはly および $\mathrm{v} の$ 陽性 率が CEA, CA19-9陽性群で有意に高かったが, stage IIに関しては両者間に差はみられなかった。一方深達 
stage I

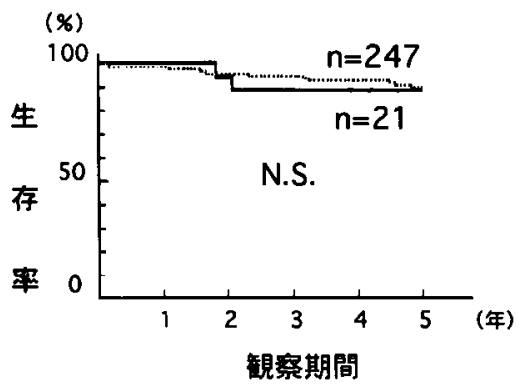

stage II

(\%)

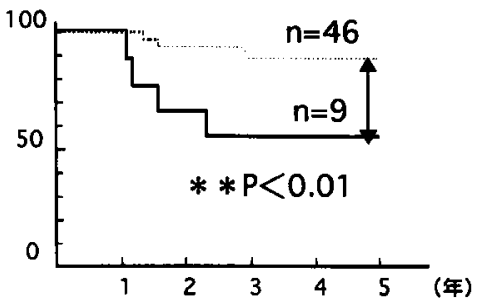

stage III

(\%)

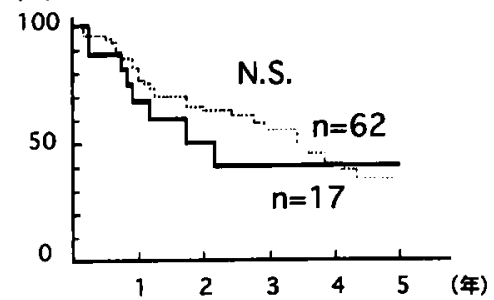

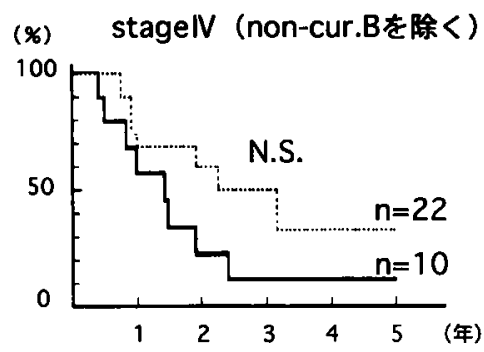


図 5 術前 CA19-9值からみた stage 別生存曲線
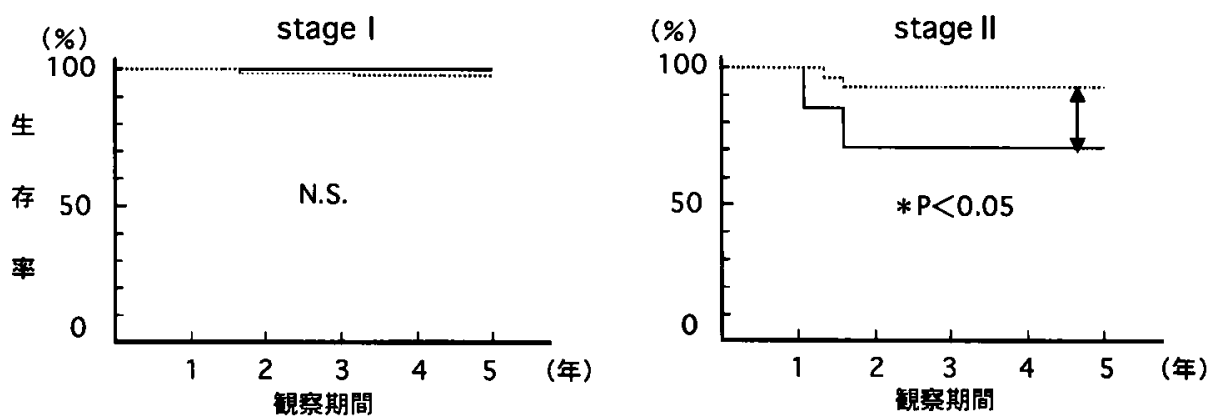

CA19-9陰性群 $(n=236)$

CA19-9陽性群 $(n=19)$

CA19-9隊性群 $(n=44)$

CA19-9陆性群 $(n=7)$

図 6 他病死症例を除いた stage I, II の CA19-9陽性群と隆性群の生存曲線の比較

表 2 他病死を除いた stage I, II 症例の背景因子

\begin{tabular}{|c|c|c|c|c|c|c|c|c|}
\hline & & & ly 陽性率 & $\mathrm{P}$ 值 & v 陽性率 & $\mathrm{P}$ 値 & $\underset{\text { 割合 }}{\mathrm{pm}_{\text {合 }}}$ & $\mathrm{P}$ 值 \\
\hline stage I & $\begin{array}{l}\text { CEA }(+) \\
\text { CEA }(-) \\
\text { CA19-9(+) } \\
\text { CA19-9(-) }\end{array}$ & $\begin{array}{l}(n=34) \\
(n=225) \\
(n=19) \\
(n=236)\end{array}$ & $\begin{array}{l}50.0 \% \\
30.4 \% \\
57.9 \% \\
31.5 \% \\
\end{array}$ & $\begin{array}{l}\mathrm{p}<0.05 \\
\mathrm{p}<0.05\end{array}$ & $\begin{array}{l}38.2 \%- \\
24.5 \%- \\
47.4 \% \\
20.9 \%-\end{array}$ & $\begin{array}{l}\text { N.S. } \\
p<0.01\end{array}$ & $\begin{array}{l}26.5 \%- \\
14.3 \%- \\
21.1 \%- \\
16.5 \%-\end{array}$ & N.S. \\
\hline stage II & $\begin{array}{l}\text { CEA (+) } \\
\text { CEA (-) } \\
\text { CA19-9(+) } \\
\text { CA19-9(-) }\end{array}$ & $\begin{array}{l}(n=5) \\
(n=46) \\
(n=7) \\
(n=44)\end{array}$ & $\begin{array}{r}100.0 \% \\
97.9 \% \\
100.0 \% \\
97.8 \%\end{array}$ & N.S. & $\begin{array}{r}100.0 \% \\
93.6 \% \\
100.0 \% \\
93.3 \%\end{array}$ & N.S. & $\begin{array}{r}100.0 \% \\
80.9 \% \\
100.0 \% \\
80.0 \%\end{array}$ & N.S. \\
\hline
\end{tabular}


度については両者間に有意差はみられなかった（表 2 ).

\section{考察}


癌組織より抽出された桾蛋白であり,CA19-9は1979年 Koprowski ら”によって細胞融合技術を用いて作成さ れたモノクローナル抗体 (1116NS19-9) により認識さ れる糖鎖抗原である。これらは腫陽マーカーとして, 大腸癌, 膵癌等の消化器癌患者の臨床に広く用いられ, 胃癌においても癌の存在診断, 進行度の判定, 手術や その他の補助療法の効果判定, 予後の予測, 再発や転 移の診断に応用されているいー4!

今回，われわれが検討した胃癌患者の術前 CEA 陽 性率は18.5”。, CA19-9陽性率は19.5ㅇ。゙あったが，一 般に胃癌患者の CEA 陽性率は17.6 22.2\%

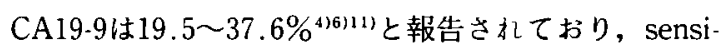
tivityはあまり高くない.

術前 CEA, CA19-9值と予後に関しては, 全症例を対 象にするとこれら腫㴼マーカー陽性例の予後は陰性例 と比して有意に不良であった。さらに腫瘍マーカー値 を 3 段階に細分化し，生存曲線を比較してみると $\mathrm{CEA} \geqq 10 \mathrm{ng} / \mathrm{ml}$, およびCA19-9 $\geqq 50 \mathrm{U} / \mathrm{ml}$ の高值群の 予後が有意に不良であった. Nakane ら"21は術前 CEA 值を 5 段階に分け生存曲線を比較した結果, <10ng/ $\mathrm{ml}$ と $\geqq 10 \mathrm{ng} / \mathrm{ml}$ の間に有意な予後の差を認め, CEA $10 \mathrm{ng} / \mathrm{ml}$ を clitical point であると強調している.同様 に三輪ら ${ }^{(3)} も \mathrm{CEA} \geqq 10 \mathrm{ng} / \mathrm{ml}$ を clitical value と報告 しているが，今回のわれわれの検討でも CEAに関し ては $10 \mathrm{ng} / \mathrm{ml}$ 以上が予後不良の大きな指標であり，さ らにCA19-9に関しては $50 \mathrm{U} / \mathrm{ml}$ 以上, 特に $100 \mathrm{U} / \mathrm{ml}$ 以上で予後不良の予測が可能である。

次に stage 別に腫湯マーカー陽性群と陰性群につい て,その予後を比較してみたが, stageの進行した stage III, IVでは予後に有意差を認めなかった。 $\mathrm{Na}$ kane ら"も stage I, II, III では CEA<5.0ng/ml とミ $10 \mathrm{ng} / \mathrm{ml}$ の間に有意な予後の差を認めたが, stage IV ては有意差を認めなかったと報告しており，高度進行 例の予後は術前 CEA, CA19-9值の高低にかかわらず 不良である.このことは stage の進んだ状態では, 深達 度, リンパ節転移, 肝転移, 腹膜播種などの因子が予 後を大きく規定し, 術前腫湟マーカ一值の予後因子と しての意義は少ないと考えられる。

一方, stage I, II では術前腫湯マーカー陽性群と陰 性群との間に予後に有意差がみられた。腫湶マーカー
が予後因子のひとつとなるかどうかを検証するのが本 論文の目的であるため,これら stage I, II 症例につい て癌と無関係な他病死症例を除外して検討してみたと ころ, stage I の CEA 陽性群は陰性群と比べ! 陽性率 が有意に高く，有意に予後不良であった。一方 stage I のCA19-9陽性群は子後に有意差はみられなかったも のの, ly 陽性率, v 陽性率が有意に高かった。したがっ て stage I症例に扑ては腫瘍マーカーは胃癌の生物 学的悪性度を反映し, 特にCEA は予後因子となりう ると考えられる。

stage II 症例においては腫瘍マーカー陽性, 陰性と $\mathrm{ly}, \mathrm{v}$ との間に有意の差は認められなかったが, CEA, CA19-9ともに陽性群は予後不良であり，それが何を反 映しているのかは明らかではないが，少なくとも予後 を予測する上で重要な因子と考えられる。

stage I で治癒切除がなされた症例でも稀に術後再 発することが報告されているが，15) 17，われわれの検 討結果と同様, 坂本ら ${ }^{1}$ も stage I, II で術前 CEA 高 值群は再発の危険が高いと報告している。

近年では $\mathrm{m}$ 癌および $\mathrm{sm}$ 癌に対し，患者の QOLを 考虑した内視鏡的粘膜切除術，胃部分切除術，腹腔鏡 下胃切除術などの縮小手術が試行され，検討が重ねら れている、縮小手術の適応に慎重でなければならない が,その際術前 CEA, CA19-9值は大きな判断材料にな ると思われる。

\section{結語}

贯癌における術前 CEA, CA19-9值が予後に与える 影響について検討した結果， stage I, II に関しては術 前 CEA，CA19-9陽性例の予後は陰性例に比して不良 であり，橄重な経過観察が必要である。

尚, 本論文の要旨は平成 7 年 9 月29日第70回中国四国外 科学会総会（岡山）にて発表した。

\section{文 献}

1）浜田吉則, 駒田尚直, 今林信康他：胃癌患者におけ る carbohydrate antigen 19-9 の臨休的意義. 日消 外会誌 $19: 909-913,1986$

2) Staab HJ, Anderer FA, Brummendorf T, et al : Prognostic value of preoperative serum CEA level compared to clinical staging. II. Stomach cancer. Br J Cancer 45:718-727, 1982

3）国枝克行, 蔭山 徹, 过 恭嗣他: 胃癌術前血清 CEA 値および組織 CEA 局在様式と予後との関連 について，日胸外会誌 $29: 677-683,1996$

4）浜副隆一, 古贺成是, 前田迪郎他：胃癌患者血清中 $の$ tissue polypeptide antigen $と$ carbohydrate 
antigen 19-90臨床的評価. 日消外会誌 $20: 29-$ 33,1987

5）胃癌研究公編：䏣癌取扱い規約. 改定第11版, 金原 出版, 東京, 1985, p1-64

6) Gold P. Freedmann SO: Specific carcinoembrionic antigen of the human digestive system. J Exp Med 122: $467-481,1965$

7) Koprowski M, Steplewski Z, Mitchell K : Colorectal carcinoma antigens detected by hybridoma antibodies. Somat Cell Genet 5 : 957 $-972,1979$

8) 蔭山徹：胃癌術前血清 CEA 值と組織 CEA 局 在样式から見た予後と, CEA陽性癌細胞の核 DNA 量からみた生物学的悪性度に関する検討。 岐阜大医紀 39:598-631, 1991

9）西田哲朗, 有馬純孝, 二見喜太郎他：胃癌と腫瘍、 一力一, その臨床病理学的意義. 福岡大医紀 18 : 401-407, 1991

10) Yerl HK, Jaffer AA, David MO, et al: Value of carcinoembryonic antigen levels in patients with resectable adenocarcinoma of the esophagus and stomach. Cancer $75: 451-456,1995$

11）西田康一, 山本健男, 吉岡敬治他：胃癌における血 清 CA19-9測定の意義. 癌と化療 1：101-108,
1986

12) Nakane $Y$, Okamura $S$, Akehira $K$, et al: Correlation of preoperative carcinoembryonic antigen levels and prognosis of gastric cancer patients. Cancer 73 : 2703-2708, 1994

13）三輪晃一, 宮崎逸夫，松木伸一他：胃癌患者の術前 CEA 測定の意義. 日消外会誌 $14 ： 1563-1570$, 1981

14) Neville AM. Laurence DJR: Report of the workshop on the carcinoembryonic antigen(CEA): The present position and proposals for future investigation. Int $\mathrm{J}$ Cancer 10 : $1-18,1974$

15）小林 理, 岡田賢三, 西蓮寺意勲他: 早期胃癌切除 後再発死亡例の検討. 外科 $52: 911-915,1990$

16）手塚秀夫, 鈴木博孝, 喜多村陽一：早期胃癌再発死 亡症例の検討。日消外会誌 $23: 2202-2208,1990$

17）黑田吉隆, 堀川直樹, 高田 理他：早期胃癌におけ る臨床病理ならびに経過の解析からみた再発例の 検討. 日消外会誌 $28: 1653-1659,1995$

18）坂本純一, 中里博昭, 峠 哲哉他：胃癌の診断, ス テージング,および予後に関する術前 CEA 值とそ の follow upの意義. 日癌治療会誌 25：10951104,1990

\title{
THE CORRELATION BETWEEN PREOPERATIVE SERUM CEA AND CA19-9 LEVELS AND POSTOPERATIVE PROGNOSIS OF GASTRIC CANCER
}

\author{
Tetsuya TANIGUCHI, Takashi SAWATA, Tetsu SHIMIZU, \\ Yoshihiro KAWAMURA and Kiyoshi KISHI \\ Department of Surgery, Tottori Prefectural Central Hospital
}

The correlation between preoperative serum CEA and CA19-9 levels and postoperative survival was examined in 552 patients undergoing gastrectomy for gastric cancer in our department in a recent 7 -year period.

As a whole the serum CEA positive-rate was $18.5 \%$ and the serum CA19-9 positive-rate was $19.5 \%$. The higher the clinical stage, the higher the positive-rate of each tumor marker elevated. The prognosis of CEA positive group and of CA19-9 positive group were significantly poorer than each negative group, especially when the serum CEA level was above $10 \mathrm{ng} / \mathrm{ml}$ and when the serum CA19-9 level was above $50 \mathrm{U} / \mathrm{ml}$.

Divided into each stage, there was no significant difference in prognosis between CEA, CA19-9 positive group and negative group in stage III and IV. On the other hand in stage I and II, the prognosis of CEA positive group was significantly poorer than that of negative group and so was the prognosis of CA19-9 positive group in stage II.

Concerned to lymphatic invasion (ly) and venous invasion (v) in stage I, the ly-positive rates in CEA positive group and CA19-9 positive group were significantly higher than those of negative groups and so was the v-positive rate of CA19-9 positive group. But there was no significant relation in stage II.

We think that preopeartive CEA and CA19-9 levels might be useful prognostic factors of gastric cancer in a low-grade stage. 